\title{
A NOVEL QUINONE ANTIBIOTIC FROM Malbranchea cinnamomea TAIM 13T54
}

\author{
Yin-Mei Chiung, Tomoyuki Fujita, Masahira Nakagawa, Hiroshi Nozaki ${ }^{\dagger}$,

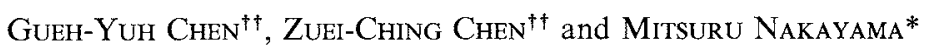 \\ Department of Agricultural Chemistry, University of Osaka Prefecture, \\ Sakai, Osaka 593, Japan \\ ${ }^{\dagger}$ Department of Biological Chemistry, Faculty of Science, Okayama University of Science, \\ Okayama 700 , Japan \\ ${ }^{\dagger}$ Department of Botany, National Taiwan University, \\ Taipei, Taiwan 10764, Republic of China
}

(Received for publication June 22, 1993)

\begin{abstract}
A novel quinone antibiotic named malbranicin was isolated from the culture filtrate and mycelium of Malbranchea cinnamomea TAIM 13T54, a thermophilic fungus. The antibiotic was elucidated to be 6-(1-acetylethyl)-2-methoxy-2,5-cyclohexadiene-1,4-dione by spectral analysis. Malbranicin exhibited antimicrobial and cytotoxic activities against Gram-positive bacteria and mammalian cell lines, respectively.
\end{abstract}

In the screening course of new metabolites from microorganisms, thermophilic fungi showed a very high ratio in producing biological active substances. The authors screened these rare fungi for production of antibiotics. Among strains isolated, TAIM 13T54 identified as Malbranchea cinnamomea was a new record in Taiwan. A novel quinone antibiotic named malbranicin was isolated from the culture filtrate and mycelium of the isolate. In this paper we describe the isolation and identification of the strain, and we also describe the production, isolation, structural determination and biological activities of malbranicin (Fig. 1).

\section{Results and Discussion}

Discovery of the Producing Strain

Various strains were isolated from field soil in Taiwan. Soil samples were heated at $60^{\circ} \mathrm{C}$ in water bath for 15 minutes, then incubated at $50^{\circ} \mathrm{C}$ on PDA containing chloramphenicol and Rose bengal. During the screen described as Experimental, we succeeded in isolating a thermophilic fungal strain TAIM 13T54 exhibiting strong activities against Staphylococcus aureus and Bacillus subtilis by disc agar diffusion assay method. Microorganisms were expected to produce special physiological active compounds after heat shock treatment as reported in finding novel polyketide antibiotic in Streptomyces venezuelae ${ }^{1)}$, but in our case, heat treatment was only used as a procedure for isolation of thermophilic fungi.

Fig. 1. The structure of malbranicin and its derivatives.

\section{Taxonomy}

Cultural and morphological characteristics of the strain TAIM 13T54 are as follows. On potato dextrose agar the strain showed good growth at $40^{\circ} \mathrm{C}$, reaching $45 \mathrm{~mm}$ long in 10 days; slow growth at $50^{\circ} \mathrm{C}$ and no growth at $30^{\circ} \mathrm{C}$. The central area of<smiles>COC1=CC(=O)C=C(C(C)C(C)=O)C1=O</smiles>

1<smiles>COc1cc(O)cc(C(C)C(C)=O)c1O</smiles>

$2 \mathrm{R}=\mathrm{H}$

$3 \mathrm{R}=\mathrm{CH}_{3} \mathrm{CO}$ 
a colony was white initially and changed to a mixture of pale Rhodonite pink, white and yellow; the reverse was Kaiser brown or dark red brown, with a strong rotten fish meal odor when matured. In description above, the capitalized color names noted was from Ridgeway ${ }^{2)}$.

Vegetative hyphae were $2 \sim 8 \mu \mathrm{m}$ in diameter and hyaline, with conspicuous swells near septa $(5 \sim 9 \mu \mathrm{m}$ in diameter). No conidiophore differentiated. Fertile tips usually bent into small loops or coils, and finally articulated into arthroconidia becoming single or chained. Conidia were yellow green, cubic and broadly elliptical or slightly curved, differing in size between $3.2 \sim 4.5 \times 3.9 \sim 7.7 \mu \mathrm{m}$, with conspicuous frills at both ends (Fig. 2).

From the mycological characteristics described above, strain TAIM 13T54 was identified as the genus Malbranchea following to the classification of thermophilic fungi ${ }^{3)}$. Because this strain showed good agreement with the description of Malbranchea cinnamomea (Lib.) VAN OOSCHOT and DE HooG ${ }^{4)}$, we have designated this strain as Malbranchea cinnamomea TAIM 13 T54.

Fig. 2. The morphology of Malbranchea cinnamomea TAIM 13 T54.

Fermentation

To improve the fermentation conditions, we investigated the effects of temperature, nitrogen sources and carbon sources. The strain produced malbranicin only between $34 \sim 44^{\circ} \mathrm{C}$ without much variation in growth. The highest yield appeared at $40^{\circ} \mathrm{C}$ (Fig. 3). The results of the study about nitrogen sources showed that yeast extract was more effective than others (Table 1), but Polypepton supplied a longer plateau. So mixtures of them in Bar represents $10 \mu \mathrm{m}$.

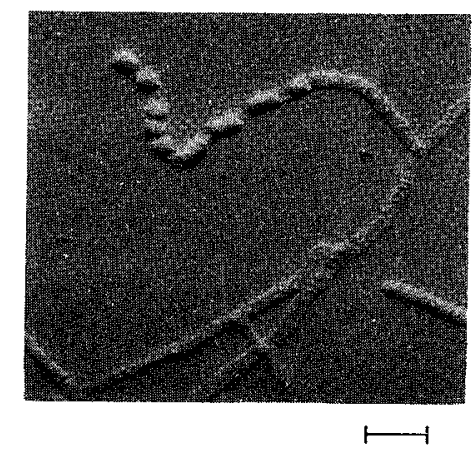

Fig. 3. Temperature effect on the yields of malbranicin. Open: malbranicin, closed: mycelial dry weight.

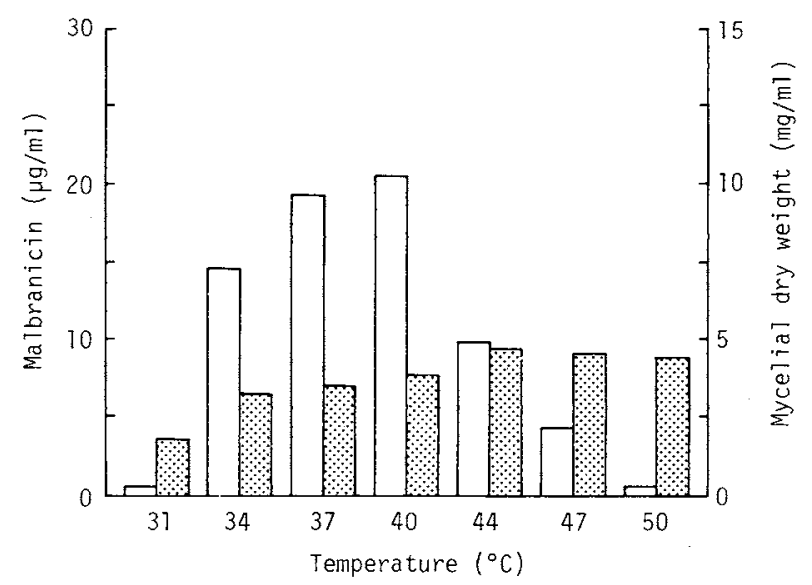

Fermentation medium: soluble starch $1.5 \%$, yeast extract $0.4 \%, \mathrm{~K}_{2} \mathrm{HPO}_{4} 0.1 \%$ and $\mathrm{MgSO}_{4} \cdot 7 \mathrm{H}_{2} \mathrm{O}$ $0.05 \%, \mathrm{pH} 7.0$.

All of the batches were incubated in L-tubes on a temperature gradient shaker for 48 hours after inoculated with $1 \%$ seed culture which was shaked with $110 \mathrm{rpm}$ at $40^{\circ} \mathrm{C}$ for 30 hours. 
Table 1. Effect of nitrogen sources on malbranicin production.

\begin{tabular}{lccc}
\hline Nitrogen sources & $\%$ & $\begin{array}{c}\text { Mycelial dry } \\
\text { weight }(\mathrm{mg} / \mathrm{ml})\end{array}$ & $\begin{array}{c}\text { Malbranicin } \\
(\mu \mathrm{g} / \mathrm{ml})\end{array}$ \\
\hline Polypepton & 0.2 & 5.00 & 15.1 \\
& 0.4 & 6.15 & 9.2 \\
C.S.L. & 0.6 & 5.25 & $<1.0$ \\
& 0.2 & 2.94 & 20.5 \\
Yeast extract & 0.4 & 5.59 & 14.2 \\
& 0.6 & 3.17 & 8.1 \\
Soybean meal & 0.2 & 4.89 & $<1.0$ \\
& 0.4 & 5.76 & 27.5 \\
& 0.6 & 5.18 & 5.7 \\
Meat extract & 0.2 & 6.8 & 2.2 \\
& 0.4 & 5.7 & 3.6 \\
& 0.2 & 8.1 & 2.1 \\
& 0.4 & 8.9 & 4.6 \\
Yeast extract/Polypepton & & 16.7 \\
& 0.6 & 8.3 & 18.5 \\
& $0.3 / 0.1$ & 5.3 & 34.5 \\
& $0.2 / 0.2$ & 5.4 & 22.3 \\
& $0.1 / 0.3$ & 6.7 & 2.0 \\
\hline
\end{tabular}

Basal medium: soluble starch $1.5 \%, \mathrm{~K}_{2} \mathrm{HPO}_{4} 0.1 \%$ and $\mathrm{MgSO}_{4} \cdot 7 \mathrm{H}_{2} \mathrm{O} 0.05 \%, \mathrm{pH} 7.0$.

All of the batches were fermented for 48 hours at $40^{\circ} \mathrm{C}$ with $110 \mathrm{rpm}$ on a reciprocal shaker after inoculated with $1 \%$ seed culture.

different ratios were tested and a mixture of $0.3 \%$ yeast extract and $0.1 \%$ Polypepton was found to be the better choice. The nitrogen basal medium thus obtained was used to examine the carbon source effect. The higher yields were appeared in batches using soluble starch as carbon source (Table 2). The best concentration was found to be $3 \%$. The time course of fermentation for malbranicin in the medium thus found is shown in Fig. 4.

\section{Isolation}

The culture filtrate (10 liters) of the strain was extracted with equal volume of ethyl acetate at $\mathrm{pH}$ 7.0. The mycelial mat was extracted twice with $70 \%$ acetone. After removal of acetone, the resulting syrup was extracted three times with 3 liters of ethyl acetate at $\mathrm{pH}$ 7.0. The combined ethyl acetate extracts were dried over anhydrous sodium sulfate and concentrated to dryness in vacuo. The residue (ca. $1.3 \mathrm{~g}$ ) was subjected to silica gel column
Table 2. Effect of carbon sources on malbranicin production.

\begin{tabular}{|c|c|c|}
\hline $\begin{array}{c}\text { Carbon sources } \\
(3 \%)\end{array}$ & $\begin{array}{c}\text { Mycelial dry } \\
\text { weight }(\mathrm{mg} / \mathrm{ml})\end{array}$ & $\begin{array}{l}\text { Malbranicin } \\
\qquad(\mu \mathrm{g} / \mathrm{ml})\end{array}$ \\
\hline Soluble starch $2 \%$ & 5.4 & 59.0 \\
\hline $3 \%$ & 5.7 & 66.2 \\
\hline $4 \%$ & 5.9 & 50.2 \\
\hline Dextrin & 6.3 & 43.0 \\
\hline Soybean oil & 15.1 & 9.4 \\
\hline Sucrose & 5.1 & 3.3 \\
\hline Lactose & 2.2 & $<1.0$ \\
\hline Fructose & 5.1 & 17.7 \\
\hline Glucose & 7.4 & 3.9 \\
\hline Ribose & 8.3 & 13.8 \\
\hline Glycerin & 7.2 & 37.4 \\
\hline Mannitol & 3.7 & 10.0 \\
\hline Erythritol & 6.3 & 12.5 \\
\hline Malonic acid & 1.9 & $<1.0$ \\
\hline Succinic acid & 2.4 & 9.0 \\
\hline
\end{tabular}

Basal medium: yeast extract $0.3 \%$, Polypepton $0.1 \%, \mathrm{~K}_{2} \mathrm{HPO}_{4} 0.1 \%$ and $\mathrm{MgSO}_{4} \cdot 7 \mathrm{H}_{2} \mathrm{O} 0.05 \%$, $\mathrm{pH} 7.0$.

All of the batches were fermented at $40^{\circ} \mathrm{C}$ for 48 hours after inoculated with $1 \%$ seed culture.

Fig. 4. Time-course of malbranicin production by Malbranchea cinnamomea TAIM 13 T54.

Malbranicin ( ) determined by the HPLC method. Mycelial dry weight (A). pH (D).
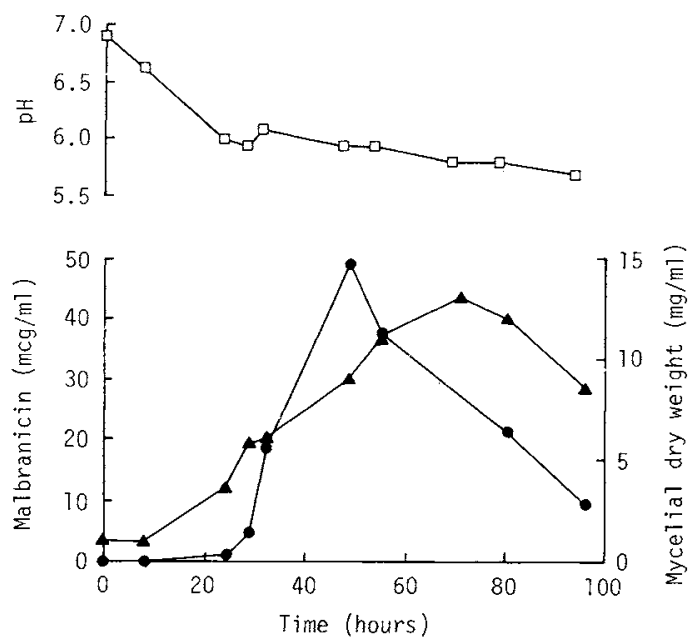

Fermentation medium: soluble starch $3 \%$, yeast extract $0.3 \%$, Polypepton $0.1 \%, \mathrm{~K}_{2} \mathrm{HSO}_{4} 0.1 \%$, $\mathrm{MgSO}_{4} \cdot 7 \mathrm{H}_{2} \mathrm{O} 0.05 \%, \mathrm{pH} 7.0$.

The batches were shaked with $110 \mathrm{rpm}$ at $40^{\circ} \mathrm{C}$ after inoculated with $1 \%$ seed which was cultured in seed medium under the same condition. 
Table 3. Physico-chemical properties of malbranicin.

\begin{tabular}{|c|c|}
\hline Appearance & Yellow needles \\
\hline $\mathrm{MP}\left({ }^{\circ} \mathrm{C}\right)$ & $112 \sim 114$ \\
\hline$[\alpha]_{\mathrm{D}}^{25}$ & $-18^{\circ}(c 0.01, \mathrm{MeOH})$ \\
\hline HREI-MS $m / z(\mathrm{M})^{+}$ & 208.0735 \\
\hline EI-MS $m / z$ & $208(\mathrm{M})^{+}, 166,151,138$ \\
\hline Molecular formula & $\mathrm{C}_{11} \mathrm{H}_{12} \mathrm{O}_{4}$ \\
\hline \multirow[t]{2}{*}{ Elemental analysis } & Found: C 63.36 , H $5.72 \%$ \\
\hline & Calcd: $\quad$ C 63.45, H $5.81 \%$ \\
\hline Color test & $\begin{array}{l}\text { Positive: } \quad 2,4 \text {-dinitrophenylhydrazine, vanillin- } \mathrm{H}_{2} \mathrm{SO}_{4} \\
\text { Negative: } \mathrm{I}_{2} \text {, Dragendorff }\end{array}$ \\
\hline Solubility & $\begin{array}{l}\text { Soluble: chloroform, benzene, EtOAc, } \mathrm{MeOH} \\
\text { Insoluble: petroleum ether }\end{array}$ \\
\hline $\mathrm{UV} \lambda_{\max }^{\mathrm{MeOH}} \mathrm{nm}(\varepsilon)$ & $258(12,400), 360(970)$ \\
\hline IR $v_{\max }$ (Neat) $\mathrm{cm}^{-1}$ & $2980(w), 2950(w), 1700(s), 1680(s), 1645(s), 1240(s)$ \\
\hline $\mathrm{TLC}^{\mathrm{a}}(\mathrm{Rf})$ & 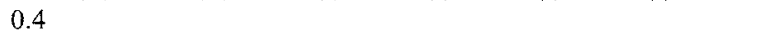 \\
\hline $\operatorname{HPLC}^{\mathrm{b}}(\mathrm{R} t)$ & 3.69 minutes \\
\hline $\mathrm{GC}^{\mathrm{c}}(\mathrm{Rt})$ & 7.16 minutes \\
\hline
\end{tabular}

chromatography $(18 \times 400 \mathrm{~mm})$ using chloroform - ethyl acetate as an eluant. The $33 \%$ ethyl acetate eluate showed antibiotic activity against Bacillus subtilis. The active fraction was concentrated in vacuo (ca. $450 \mathrm{mg}$ ), and rechromatographed on a silica gel column $(14 \times 250 \mathrm{~mm})$ using a 5:1 mixture of chloroform - ethyl acetate. The elution was monitored by TLC under a UV lamp. The active fractions showing one spot on TLC were combined and then concentrated to dryness in vacuo. After washed with hexane and benzene, a faint yellow powder was first crystallized in a chloroform - methanol mixture, and then recrystallized in methanol. Malbranicin thus obtained was proved to be homogeneous by silica gel TLC, reverse phase HPLC and GC.

\section{Physico-chemical Properties}

Malbranicin (1) is soluble in chloroform, ethyl acetate, acetone, methanol and ether, sparingly soluble in hexane and benzene, and almost insoluble in petroleum ether. It gave a positive color reaction with 2,4-dinitrophenylhydrazine, suggesting that it has a ketone group. The crystals of 1 showed a melting point of $112 \sim 114^{\circ} \mathrm{C}$ with $[\alpha]_{\mathrm{D}}^{25}-18^{\circ}(c 0.01, \mathrm{MeOH})$. The molecular formula of 1 was determined to be $\mathrm{C}_{11} \mathrm{H}_{12} \mathrm{O}_{4}$ by EI-MS: $m / z 208\left(\mathrm{M}^{+}\right)$, CI-MS: $m / z 209(\mathrm{M}+1)^{+}$, FAB-MS: $m / z 209(\mathrm{M}+1)^{+}$, high resolution mass spectrometry $\left[m / z 208.0735\left(\mathrm{M}^{+}\right)\right.$, calcd for $\left.\mathrm{C}_{11} \mathrm{H}_{12} \mathrm{O}_{4}: 208.0736\right]$ and elemental analysis. The physico-chemical properties of $\mathbf{1}$ are summarized in Table 3.

\section{Structure}

The molecular formula of 1 was determined to be $\mathrm{C}_{11} \mathrm{H}_{12} \mathrm{O}_{4}$ by HRMS and elemental analysis, so the unsaturation number of 1 was counted to be six. The existence of two double bonds and three carbonyl carbons was indicated by ${ }^{1} \mathrm{H}$ and ${ }^{13} \mathrm{C}$ NMR spectra (Table 4), so 1 was deduced to contain a ring. A ketone at $1700 \mathrm{~cm}^{-1}$ and two conjugated ketones at 1680 and $1645 \mathrm{~cm}^{-1}$ were also suggested by IR spectrum (Fig. 5), and the UV spectrum of 1 also revealed it belonging to a benzoquinone. A methoxyl group $\left(\delta_{\mathrm{H}} 3.84, \delta_{\mathrm{C}} 56.2\right)$ was suggested to locate on benzoquinone because of a benzenoid signal at 
Fig. 5. IR spectrum of malbranicin.

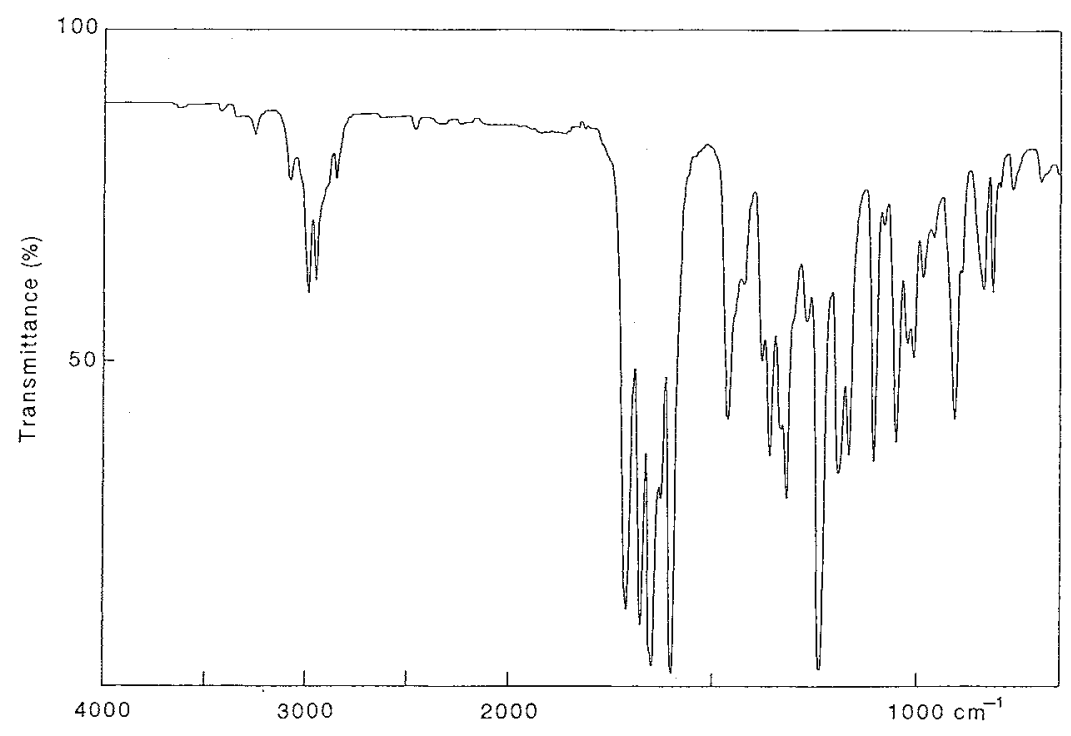

$\delta_{\mathrm{C}} 158.6$. The absorption in UV spectrum as well as the marked difference in the $\varepsilon$ value between $258 \mathrm{~nm}$ $(\varepsilon=12,400)$ and $360 \mathrm{~nm}(\varepsilon=970)$ resulted in the conclusion that 1 belongs to a alkylated 2 -methoxy1,4-benzoquinone ${ }^{5}$.

A signal at $\delta_{\mathrm{C}} 145.9$ was assigned to a carbon to be linked with another substituent. Considering the coupling constant $(J=2.4 \mathrm{~Hz})$ between the signals at $\delta_{\mathrm{H}} 5.95\left(\delta_{\mathrm{C}} 107.3\right)$ and $6.53\left(\delta_{\mathrm{C}} 133.5\right)$, these two methine protons were speculated to be meta-positioned, so alkyl substitute would be at C-6. The remaining signals composed of $\mathrm{C}_{4} \mathrm{H}_{7} \mathrm{O}$
Table 4. ${ }^{1} \mathrm{H}$ and ${ }^{13} \mathrm{C}$ NMR data of malbranicin in $\mathrm{CDCl}_{3}$.

\begin{tabular}{cclc}
\hline Carbon & $\delta_{\mathrm{C}}$ & Proton & $\delta_{\mathrm{H}}$ \\
\hline 1 & $186.7^{*}$ & & - \\
2 & 158.6 & & - \\
3 & 107.3 & $3-\mathrm{H}$ & $5.95(\mathrm{~d}, 2.4)$ \\
4 & $181.3^{*}$ & & - \\
5 & 133.5 & $5-\mathrm{H}$ & $6.53(\mathrm{dd}, 2.4,1.2)$ \\
6 & 145.9 & & - \\
7 & 45.2 & $7-\mathrm{H}$ & $3.95(\mathrm{dq}, 7.3,1.2)$ \\
8 & 206.7 & & - \\
9 & 28.7 & $-\mathrm{COCH}_{3}$ & $2.29(\mathrm{~s})$ \\
10 & 14.3 & $-\mathrm{CH}_{3}$ & $1.35(\mathrm{~d}, 7.3)$ \\
11 & 56.2 & $-\mathrm{OCH}_{3}$ & $3.84(\mathrm{~s})$ \\
\hline
\end{tabular}

* May be exchanged. was equivalent to this aliphatic side chain which was assigned to acetyl $\left(\delta_{\mathrm{C}} 206.7\right.$ and $\left.\delta_{\mathrm{H}} 2.29, \delta_{\mathrm{C}} 28.7\right)$ and ethylidene $\left(\delta_{\mathrm{H}} 1.35 \mathrm{~d}, \delta_{\mathrm{C}} 14.3 ; \delta_{\mathrm{H}} 3.95 \mathrm{dq}\right.$, $\left.\delta_{\mathrm{C}} 45.2\right)$ residues. The only way of combination came to a acetyl-ethyl chain. This elucidated substitute is just the same as acetoin, and was further confirmed by direct comparison of ${ }^{1} \mathrm{H}$ and ${ }^{13} \mathrm{C}$ NMR spectra. The fragment ions at $m / z 166,151$ and 138 in the EI-MS spectrum (Table 3) also supported the presence of this side chain. Finally the structure of 1 was concluded as 6-(1-acetylethyl)-2-methoxy-2,5-cyclohexadiene-1,4-dione.

Based on the long range coupling constant $\left(J_{\mathrm{ax}}=1.2 \mathrm{~Hz}\right)$ between the quartet methine and the quinone proton at $\delta_{\mathrm{H}} 6.53$, this quinone proton was determined at $\mathrm{C}-5$. Finally from the results deduced from ${ }^{1} \mathrm{H}-{ }^{1} \mathrm{H}$ and ${ }^{1} \mathrm{H}_{-}{ }^{13} \mathrm{C}$ COSY NMR spectra, the assignment of all signals of ${ }^{1} \mathrm{H}$ and ${ }^{13} \mathrm{C}$ was completed except two ketone signals of $\delta_{\mathrm{C}} 186.7$ and 181.3 . These two signals were temporarily assigned to $\mathrm{C}-1$ and $\mathrm{C}-4$, because in the ketone carbons of benzoquinone, one on the side of stronger electron-negativity always produces a signal in a lower field than the other one ${ }^{6)}$. The total assignment is shown in Table 4. 
Fig. 6. A perspective view of diacetate (3) of dihydromalbranicin.

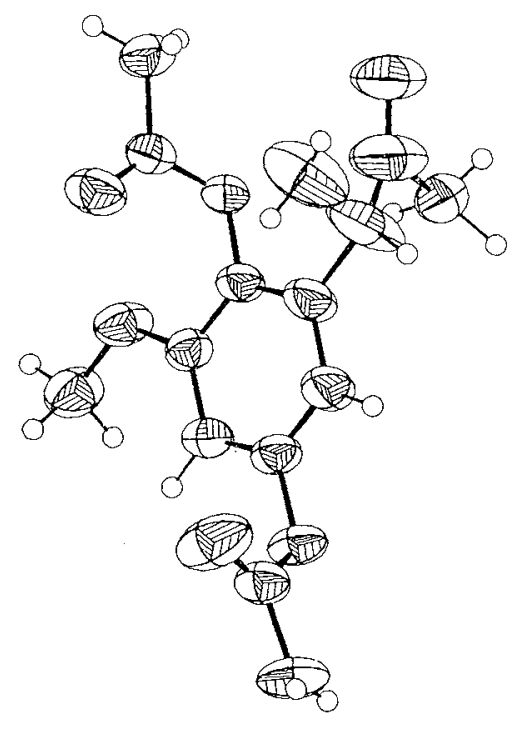

Table 5. Antimicrobial spectrum of malbranicin.

\begin{tabular}{lc}
\hline \multicolumn{1}{c}{ Microorganisms } & MIC $(\mu \mathrm{g} / \mathrm{ml})$ \\
\hline Staphylococcus aureus IFO3060 & 25 \\
S. epidermidis IFO209D & 100 \\
S. xylosus ATCC2997! & 100 \\
Bacillus subtilis ATCC6633 & 25 \\
Micrococcus luteus ATCC9341 & 100 \\
M. roseus IFO3768 & 6.25 \\
Enterococcus faecalis IFO12968 & $>100$ \\
Escherichia coli IFO3301 & $>100$ \\
Serratia marcecens IFO12648 & $>100$ \\
Pseudomonas aeruginosa IFO13275 & $>100$ \\
Candida albicans IFO589 & $>200$ \\
Saccharomyces cerevisiae & $>200$ \\
Aspergillus niger IFO4416 & $>200$ \\
Fusarium oxysporum IFO5880 & 200 \\
Penicillium chrysogenum IFO4897 & $>200$ \\
\hline
\end{tabular}

Validity of the proposed conclusion about the structure of 1 was chemically checked as follows: hydrogenation of $\mathbf{1}$ yielded dihydromalbranicin (2), which had two phenolic hydroxyl groups, then $\mathbf{2}$

was converted to the corresponding diacetate (3) by the method described in Experimental. The UV and IR spectra of the two derivatives clearly showed the transformation from quinoid to benzenoid. Only the saturated ketone signal was observed to be unchanged at $1700 \mathrm{~cm}^{-1}$ in $\mathbf{3}$. The computer-generated perspective view of 3 , which was deduced from $X$-ray crystallographic analysis, is shown in Fig. 6. We will report the details of this study elsewhere in future ${ }^{7}$.

Among benzoquinones, malbranicin is the first compound with an acetyl-ethyl substitute.

\section{Biological activity}

The results of antimicrobial evaluation are summarized in Table 5, showing that 1 had weak activity against Gram-positive bacteria and no activity on Gram-negative bacteria. Slight activity against some fungi was noted. 1 was found to be cytotoxic at $0.7 \mu \mathrm{g} / \mathrm{ml}$ against P388 cells and $2.8 \mu \mathrm{g} / \mathrm{ml}$ to $\mathrm{KB}$ cells, indicative of a slight selective toxicity between two cell lines.

\section{Experimental}

Isolation of the Strains

Fungal strains were isolated on potato dextrose agar and corn meal agar plates containing chloramphenicol $(0.1 \mathrm{mg} / \mathrm{ml})$ and Rose bengal $(0.05 \mathrm{mg} / \mathrm{ml})$ after 3 days incubation at $50^{\circ} \mathrm{C}$. All of the soil samples were digged out from about $10 \mathrm{~cm}$ depth from various districts in Taiwan. Each sample was treated with hot water for 15 minutes at $60^{\circ} \mathrm{C}$ before spreaded on isolation media.

Screen and Fermentation

The pure cultures were inoculated in 250-ml Erlenmeyer flasks containing $50 \mathrm{ml} \mathrm{YpSs} \mathrm{medium} \mathrm{(soluble}$ starch $1.5 \%$, yeast extract $0.4 \%, \mathrm{~K}_{2} \mathrm{HPO}_{4} 0.1 \%$ and $\mathrm{MgSO}_{4} \cdot 7 \mathrm{H}_{2} \mathrm{O} 0.05 \%, \mathrm{pH} 7.0$ ), and incubated at $40^{\circ} \mathrm{C}$ for 4 days with shaking at $180 \mathrm{rpm}$. The detection for production of antibiotics was monitored by disc agar diffusion assay method using Staphylococcus aureus as detectors.

Batch cultures for the study on the effects of the temperature, nitrogen sources and carbon sources 
were incubated in 500-ml flasks with $120 \mathrm{ml}$ medium for 48 hours on a reciprocal shaker at $110 \mathrm{rpm}$, after inoculating with $1 \%$ of seed cultures incubated at $40{ }^{\circ} \mathrm{C}$ for 30 hours in seed medium (soluble starch $1.5 \%$, Polypepton $0.4 \%$, yeast extract $0.4 \%, \mathrm{~K}_{2} \mathrm{HPO}_{4} 0.1 \%$ and $\mathrm{MgSO}_{4} \cdot 7 \mathrm{H}_{2} \mathrm{O} 0.05 \%$, pH 7.0 ). The potency of the production with nitrogen sources was examined at three different concentrations.

The culture fluid for isolation was fermented for 48 hours with a medium composed of soluble starch $3.0 \%$, yeast extract $0.3 \%$, Polypepton $0.1 \%, \mathrm{~K}_{2} \mathrm{HPO}_{4} 0.1 \%$ and $\mathrm{MgSO}_{4} \cdot 7 \mathrm{H}_{2} \mathrm{O} 0.05 \%(\mathrm{pH} 7.0)$ under the same condition.

Assay of Antibacterial Activities

The test organisms were suspended in YDF medium (glucose 3\%, Polypepton $0.2 \%$, yeast extract $0.1 \%, \mathrm{~K}_{2} \mathrm{HPO}_{4} \quad 0.1 \%, \mathrm{MgSO}_{4} \cdot 7 \mathrm{H}_{2} \mathrm{O} \quad 0.1 \%, \mathrm{NaCl} \quad 0.05 \%, \mathrm{CaCl}_{2} \quad 0.03 \%, \mathrm{FeCl}_{2} \quad 0.00002 \%, \mathrm{ZnSO}_{4}$ $0.00003 \%$, pH 7.0, agar $2 \%$ ). The samples were first separated into cell mass and supernatant by filtration, then the culture fluids and mycelial mat were extracted with ethyl acetate at $\mathrm{pH} 7.0$ and acetone, respectively. Aliquots of extracts were applied to $8 \mathrm{~mm}$ paper dises and bioautographed with silica gel TLC.

Quantitative Analysis

The yields of 1 were determined by HPLC. The standard curve was done by standard solutions prepared from crystals. The aliquots described as above were evaporated and resolved in methanol for quantification.

Biological Activity

The MIC was determined by the serial dilution assay method after a test microorganism was incubated at $38^{\circ} \mathrm{C}$ for $18 \sim 42$ hours in Mueller-Hinton agar for bacteria and $27^{\circ} \mathrm{C}$ for 3 days in Sabouraud Dextrose agar for fungi. $\mathrm{IC}_{50}$ values were determined by using 24 hours incubates of $1 \times 10^{3}$ cells/well of $\mathrm{KB}$ cell and P388 cell line. After further 3 days incubation with 1 in various concentration, the viability was judged by crystal violet staining.

\section{Spectroscopy}

Melting points were determined with a Yanagimoto micro melting point apparatus and were uncorrected. UV spectra were recorded on a Shimadzu double beam spectrophotometer UV-180. IR spectra were determined on a Perkin Elmer FT-IR spectrophotometer 1760 or a Hitachi infrared spectrophotometer 260-10. Optical rotations were measured with a JASCO DIP-SL automatic polarimeter. NMR spectra were recorded on a JEOL JNM-GX270 spectrometer. Mass spectra were recorded on a JEOL JMS-AX500 mass spectrometer. Analysis of $\mathbf{1}$ and its derivatives were fullfilled on a Hitachi liquid chromatograph L-6200 and a Hitachi gas chromatograph G3000.

Dihydromalbranicin (2)

Malbranicin (1) (58 mg) was hydrogenated in the presence of $10 \% \mathrm{Pd}-\mathrm{C}(1 \mathrm{mg})$ in $\mathrm{MeOH}(5 \mathrm{ml})$ under $\mathrm{H}_{2}$ gas for 2 hours at room temperature. After catalyst had been filtered off, the filtrate was evaporated in vacuo. Dihydromalbranicin (2) was obtained as colorless film, Rf 0.05 (benzene - ethyl acetate, $5: 1, \mathrm{v} / \mathrm{v}$ on a silica gel TLC); Rt 9.26 minutes on GC. EI-MS $m / z 210\left(\mathrm{M}^{+}\right), 167,152,135 .{ }^{1} \mathrm{H}$ NMR: $(270 \mathrm{MHz}$, $\left.\mathrm{CD}_{3} \mathrm{OD}\right) \delta 1.35(3 \mathrm{H}, \mathrm{d}, J=7.0 \mathrm{~Hz}), 2.12(3 \mathrm{H}, \mathrm{s}), 3.90(3 \mathrm{H}, \mathrm{s}), 4.17(1 \mathrm{H}, \mathrm{q}, J=7.0 \mathrm{~Hz}), 6.20(1 \mathrm{H}, \mathrm{d}$, $J=2.7 \mathrm{~Hz}), 6.46(1 \mathrm{H}, \mathrm{d}, J=2.7 \mathrm{~Hz}), 7.88(1 \mathrm{H}, \mathrm{br}), 8.75(1 \mathrm{H}, \mathrm{br}) .{ }^{13} \mathrm{C}$ NMR: $\left(67.5 \mathrm{MHz}, \mathrm{CD}_{3} \mathrm{OD}\right) \delta 15.9$ (q, C-10), 28.3 (q, C-9), 47.9 (d, C-7), 56.4 (q, $\mathrm{OCH}_{3}$ ), 99.8 (d, C-3), 106.5 (d, C-5), 128.8 (s, C-6), 137.9 (s, C-2), $149.6(\mathrm{~s}, \mathrm{C}-4$ or 1$), 151.4(\mathrm{~s}, \mathrm{C}-1$ or 4$), 212$ (s, C-8). 2 was immediately subjected to acetylation without purification.

Diacetate (3) of dihydromalbranicin (2)

A mixture of dihydromalbranicin (2), acetic anhydride $(1.5 \mathrm{ml})$ and pyridine $(1 \mathrm{ml})$ was kept at room temperature for 24 hours and then poured into $\mathrm{H}_{2} \mathrm{O}(15 \mathrm{ml})$. The mixture was extracted with chloroform and washed with $5 \% \mathrm{HCl}$ solution. After the solvent was evaporated, the residue was purified by silica gel chromatography to give diacetate $(3)(78 \mathrm{mg})$. It gave colorless cubic crystals from ether or acetone. Rf 0.53 (benzene - ethyl acetate, 5:1, v/v on a silica gel TLC); Rt 10.54 minutes on GC; mp $101 \sim 102^{\circ} \mathrm{C}$, 
$[\alpha]_{\mathrm{D}}^{25}-81^{\circ}(c 0.01, \mathrm{MeOH}), \mathrm{UV} \lambda_{\max }^{\mathrm{MeOH}} \mathrm{nm}(\varepsilon) 225(7,640), 273(5,470)$, EI-MS $m / z 294\left(\mathrm{M}^{+}\right), 166,138$, 107. ${ }^{1} \mathrm{H}$ NMR: $\left(270 \mathrm{MHz}, \mathrm{CDCl}_{3}\right) \delta 1.23(3 \mathrm{H}, \mathrm{d}, J=7.0 \mathrm{~Hz}), 1.95(3 \mathrm{H}, \mathrm{s}), 2.21,2.24\left(\right.$ each $\left.3 \mathrm{H}, \mathrm{s}, \mathrm{OCOCH}_{3}\right)$, $3.72(3 \mathrm{H}, \mathrm{s}), 3.69(1 \mathrm{H}, \mathrm{q}, J=7.0 \mathrm{~Hz}), 6.46(1 \mathrm{H}, \mathrm{d}, J=2.7 \mathrm{~Hz}), 6.60(1 \mathrm{H}, \mathrm{d}, J=2.7 \mathrm{~Hz}) .{ }^{13} \mathrm{C} \mathrm{NMR}:(67.5 \mathrm{MHz}$, $\left.\mathrm{CDCl}_{3}\right) \delta 15.9(\mathrm{q}, \mathrm{C}-10), 20.0,21.0\left(\right.$ each s, $\left.\mathrm{OCOCH}_{3}\right), 28.1$ (q, C-9), 47.9 (d, C-7), 56.1 (q, $\mathrm{OCH}_{3}$ ), 105.3 (d, C-3), 112.6 (d, C-5), 134.5 (s, C-6 or 2), 135.5 (s, C-2 or 6), 149.6 (s, C-4 or 1), 151.9 (s, C-1 or 4), $168.5,169.0$ (each s, $\mathrm{OCOCH}_{3}$ ), 207.6 (s, C-8).

\section{Acknowledgments}

We are thankful to Dr. SHINJI TANIMORI in our laboratory for advice about preparation of derivatives.

\section{References}

1) Doull, J. L., S. W. Ayer, A. K. Singh \& P. Thibault: Production of a novel polyketide antibiotic, jadomycin B, by Streptomyces venezuelae following heat shock. J. Antbiotics 46: 869 871, 1993

2) RIDGEWAY, R. ( $E d$.): Color Standards and Nomenclature. R. Rigeway, 1912

3) SIGLER, L.: Trichothecium cinnamoraneus, an earlier name for the thermophilic hyphomycete Malbranchea surfurea. Mycologia 79: 142 143, 1987

4) Chen, G. Y. \& Z. C. Chen: Thermophilic and thermotolerant fungi in Taiwan (1). Trans. Mycologic. Soc. Rep. China: $1 \sim 72,1988$

5) Thompson, R. H.: Chapter 2. Indentification. In The Naturally Occurring Quinones. 2nd Ed., pp. 44 50, Academic Press, 1971

6) Breitmaier, E. \& W. Voflter: 4: ${ }^{13} \mathrm{C}$ NMR spectra of organic compounds, quinones and annulenones. In Carbon-13 NMR Spectroscopy. 3rd Ed. pp. 222 226, VCH Verlagsgesellschaft, Federal Republic of Germany, 1986

7) Crystal data will be described in detail elsewhere. 